\title{
PENERAPAN IPAT-BO GUNA MENINGKATKAN PRODUKTIVITAS PADI PADA LAHAN KERING DI ERA REVOLUSI INDUSTRI 4.0
}

\author{
Erna Hartati ${ }^{1}$, Twen O. Dami Dato ${ }^{1}$, Stef T.Temu ${ }^{1}$, G.A.Y. Lestari ${ }^{1}$ dan Markus M. \\ Kleden ${ }^{1}$
}

${ }^{1}$ Fakultas Peternakan Universitas Nusa Cendana, Kupang

Email: mkleden21@gmail.com

\begin{abstract}
Rice is a major issue in food security and independence because more than $90 \%$ of the population in Indonesia is highly dependent on rice. The need for rice is increasing as the population exponentially grows, but the area of paddy fields is decreasing. In the era of the industrial revolution 4.0, one of the goals was to increase the knowledge and skills of the farming community. In this connection, the attention of the government and the community is focused on increasing rice production through various innovations and the use of rice intensification technology based on the use of organic fertilizer. Innovation use of ABG (Amazing Bio Growth) biostimulant fertilizer with a target of achieving 8-15 tons / ha of rice compared to conventional 3-4 tons / ha. Efforts to increase rice production with the technology "Organic-Based Aerobic Controlled Rice Intensification (IPAT-BO)" is the answer to support the industrial revolution 4.0 in agriculture. The success of IPAT-BO technology in irrigated rice fields and rainfed rice fields apparently can also be applied in rice fields that use live water or water from bore wells on dry land in semiarid tropical ecosystems in NTT. IPAT-BO technology applied to farmers in Bipolo Village, Sulamu and Babau Districts, East Kupang District, Kupang Regency using limited water along with drainage arrangements on dry land, grain production can reach 6-8 tons / ha. The successful application of this technology is highly dependent on the development of the root system, biodiversity and balance in the supply of nutrients.
\end{abstract}

Keywords: Food independence; ABG technology; drainage; nutrition; limited water

\begin{abstract}
ABSTRAK
Beras merupakan isu utama dalam ketahanan dan kemandirian pangan karena lebih dari $90 \%$ penduduk di Indonesia sangat tergantung pada beras. Kebutuhan beras semakin meningkat seiring pertumbuhan eksponensial penduduk, namun luas lahan sawah semakin berkurang. Di era revolusi industri 4.0 salah satu sasarannya adalah peningkatan pengetahuan dan keterampilan masyarakat tani. Dalam kaitannya dengan hal tersebut, perhatian pemerintah dan masyarakat difokuskan untuk meningkatkan produksi padi melalui berbagai inovasi dan penggunaan teknologi intensifikasi padi berbasis pada penggunaan pupuk organik. Terobosan penggunaan biostimulan pupuk ABG (Amazing Bio Growth) dengan target pencapaian produksi padi 8-15 ton/ha dibanding dengan produksi 3-4 ton/ha secara konvensional. Upaya peningkatan produksi padi dengan teknologi "Intensifikasi Padi Aerob Terkendali Berbasis Organik (IPAT-BO)" merupakan jawaban untuk mendukung revolusi industri 4.0 di bidang pertanian. Keberhasilan teknologi IPAT-BO di lahan sawah irigasi dan sawah tadah hujan ternyata juga dapat diterapkan di lahan sawah yang menggunakan air hidup atau air dari sumur bor pada lahan kering di ekosistem tropis semi kering di NTT. Teknologi IPAT-BO yang diterapkan pada petani di Desa Bipolo, Kecamatan Sulamu dan Babau, Kecamatan Kupang Timur, Kabupaten Kupang dengan menggunakan air secara terbatas disertai pengaturan drainase di lahan kering, produksi gabahnya dapat mencapai 6-8 ton/ha. Keberhasilan penerapan teknologi tersebut sangat tergantung pada perkembangan sistem perakaran, keanekaragaman hayati dan keseimbangan pasokan nutrisi.
\end{abstract}

Kata kunci: Kemandirian pangan; teknologi $\mathrm{ABG}$; drainase; nutrisi; air terbatas

\section{PENDAHULUAN}

Beras merupakan isu utama dalam ketahanan dan kemandirian pangan. Akan tetapi sampai saat ini hasil tanaman padi yang diolah menjadi beras merupakan bahan pangan utama untuk memenuhi kebutuhan karbohidrat yang semakin meningkat karena $90 \%$ penduduk di Indonesia sangat tergantung pada beras. Kebutuhan beras semakin meningkat seiring pertumbuhan eksponensial penduduk, namun sebaliknya luas lahan persawahan di Indonesia setiap tahun semakin berkurang karena sebagian besar sudah beralih fungsi menjadi perumahan ataupun perkantoran. Permasalahan yang dihadapi saat ini bagaimana upaya yang harus dilakukan oleh pemerintah dan masyarakat petani untuk memenuhi permintaan pangan berasal dari beras yang harus tersedia sepanjang tahun dengan harga yang cukup terjangkau bagi masyarakat menegah ke bawah. 
Untuk mengatasi masalah tersebut pemerintah telah melakukan tindakan melalui berbagai program seperti pencetakan sawah baru dan program intensifikasi untuk meningkatkan produktivitas padi dan Upaya Penanganan Khusus (UPSUS), namun belum berhasil menaikkan produksi padi secara signifikan. Keragaan produktivitas padi di Indonesia saat ini berkisar 3-8 ton/ha, bahkan di daerah tertentu 5 ton/ha. Program ini disebarluaskan ke seluruh provinsi di Indonesia termasuk di Nusa Tenggara Timur (NTT) yang diklasifikasikan sebagai daerah ekosistem semi arid (tropis semi kering) yang didominasi oleh lahan kering dengan sumber air terbatas dan hanya mengandalkan sumber air hujan atau disebut sawah tadah hujan, dimana lahan sawahnya hanya dapat digunakan satu kali per tahun. Akibatnya upaya untuk membangun ketahanan dan kemandirian pangan menjadi sulit.

Daerah tropis iklim semi kering merupakan daerah dengan musim hujan yang relatif pendek yaitu sekitar 3-4 bulan dan musim kemarau yang relatif panjang yaitu sekitar 8-9 bulan per tahun (Katipana dan Hartati, 2012). Lebih lanjut dinyatakan bahwa di daerah ini umumnya curah hujan rendah yaitu berkisar 254-508 mm/tahun, sehingga ketersediaan air sangat terbatas. Menurut Ningsih (2014), tanaman padi dapat tumbuh secara baik apabila struktur tanah ringan, drainase baik dan cukup unsur hara; dengan demikian produktivitas padi tinggi.

Oleh karena itu, di era revolusi industri 4.0 pada daerah yang didominasi lahan kering dibutuhkan terobosan teknologi yang mampu meningkatkan hasil padi secara nyata menggunakan pupuk biostimulan ABG (Amazing Bio Growth) dengan target capaian produksi 8-15 ton/ha. Teknologi andalan yang sudah terbukti mampu mencapai hasil tersebut di atas adalah dengan menggunakan "Teknologi Peningkatan Produksi Padi ABG" dengan metoda "Intensifikasi Padi Aerob Terkendali Berbasis Organik (IPAT-BO)" yang dikenal dengan program "TP2 Padi ABG metoda IPAT-BO" (Simarmata, 2008). TP2 Padi ABG metoda IPAT-BO merupakan solusi yang tepat karena metoda penanaman dirancang dengan teknologi hemat air, hemat pupuk anorganik dan hemat benih. Teknologi ini menitikberatkan pada pemanfaatan dan pengelolaan kekuatan sumber daya tanah (soil biological power) secara terpadu untuk meningkatkan produktivitas tanaman padi yang ramah lingkungan. Keunggulan utama dalam upaya peningkatan produksi padi dengan metode IPAT-BO adalah hemat air dan bibit, hemat pupuk anorganik (sekitar 50\%), hemat pestisida. Produktivitas tinggi (8-15ton/ha) dan penerapannya mudah dan ramah lingkungan.

Beberapa peneliti sudah mengkaji penerapan IPAT-BO pada lahan sawah irigasi dan memperoleh peningkatan produksi padi $>50 \%$ yaitu dari 6 ton/ha menjadi 9,1 ton/ha gabah kering panen (Ningsih dan Suharjanto, 2012; Hingdri et al., 2013). Hasil penelitian lainnya yaitu pada lahan sawah tadah hujan, penerapan teknologi IPAT-BO ini mampu meningkatkan produksi padi sebesar $14,11 \%$ dan secara finansial telah menguntungkan dengan BC Ratio 1,2 (Nana \& Surdianto, 2013).

Keberhasilan metoda IPAT-BO di lahan sawah irigasi dan sawah tadah hujan juga tidak menutup kemungkinan juga dapat diterapkan di lahan sawah yang menggunakan air dari mata air atau air dari sumur bor pada lahan kering di daerah tropis semi kering di NTT. Keberhasilan tersebut sangat tergantung pada perkembangan sistem perakaran, keanekaragaman hayati dan keseimbangan pasokan nutrisi yang juga berpeluang dilakukan di lahan sawah pada lahan kering menggunakan air dari mata air karena teknologi ini hemat air atau menggunakan air terbatas dengan pengaturan drainase. Untuk keseimbangan pasokan nutrisi dilakukan pengaturan pemberian pupuk. Selain pengaturan drainase dan pasokan pupuk juga yang menentukan keberhasilan teknologi ini adalah varietas padi yang digunakan dan pengaturan jarak tanam (Simarmata, 2008). 
Tujuan keberlanjutan pemberdayaan masyarakat di era revolusi industri 4.0 dengan penerapan intensifikasi padi menggunakan teknologi IPAT-BO dalam upaya meningkatkan produktivitas padi pada lahan kering agar kehidupan petani ikut menjadi lebih baik.

\section{METODE KEGIATAN}

Metode yang digunakan untuk mencapai tujuan dalam penerapan teknologi IPAT-BO adalah action research atau penerapan teknologi secara holistic dan terencana melalui kegiatan pelatihan/penyuluhan, demplot dan pendampingan langsung di lapangan. Dalam proses penyuluhan, indikator partispatif masyarakat dapat diukur melalui jumlah kehadiran peserta dan respon balik dari para peserta. Tingkat kehadiran peserta mecapai $100 \%$. Jumlah ini sama dengan yang dilaporkan Kleden dan Nenobais (2018) yang menyatakan tingkat partisipasi masyarakat anggota kelompok mencapai $100 \%$. Angka partisipasi masyrakat yang tinggi menunjukkan adanya kesadaran masyarakat dalam memperoleh informasi baru. Tingginya partisipasi anggota kelompok dapat digunakan sebagai indikator dalam revolusi industri 4,0 karena peningkatan pengetahuan masyarakat juga merupakan salah satu sasaran revolusi industri 4,0. Peningkatan pengetahuan masyarakat dan keterampilan akan berdampak pada perubahan perilaku dalam sistim usahatani sehingga diharapkan keberlanjutan program IPAT-BO dapat dipertahankan. Keseluruhan kegiatan dilakukan secara partisipatif antara pendamping dan kelompok tani untuk meningkatkan produktivitas tanaman padi. Produksi padi yang ditargetkan yaitu terjadi peningkatan sebesar $100 \%$ dibanding sebelum menggunakan teknologi IPAT-BO.

Kegiatan dilakukan di lahan petani melalui beberapa tahap yaitu berkoordinasi dengan petani, penetapan luas lahan demplot, persiapan lahan dan pelaksanaan.

Melalui Program Kemitraan Wilayah (PKW) dalam proses menanam padi menggunakan teknologi IPAT-BO (Simarmata, 2008) diawali dengan persiapan lahan dan setelah diolah diberikan pupuk organik bokashi secara merata. Tahapan seleksi benih (menggunakan bibit padi Impari-6) dilakukan seagai berikut:

a. Bahan: benih $15 \mathrm{~kg}$ (kebutuhan $1 \mathrm{ha}$ ), garam, 1 butir telur ayam, dan air sekitar 10-20 liter

b. Sediakan air dalam ember sebanyak 10-20 liter, masukan telur dalam air (telur akan tenggelam di dasar ember), kemudian tambahkan garam sedikit demi sedikit sambil diaduk dengan tangan. Jika telur terapung, maka kadar garam sudah cukup, kemudian telur dikeluarkan.

c. Masukan benih ke dalam larutan air garam tadi dan aduk dengan tangan. Benih yang terapung dibuang, sedangkan benih yang tenggelam adalah benih yang baik untuk disemaikan.

d. Air garam dibuang, kemudian benih yang tenggelam tersebut dibilas dengan air bersih berulang-ulang, lalu dimasukan ke dalam karung plastik dan diremdam dalam air (karung harus terendam/tenggelam) selama 12 jam (semalam).

e. Setelah itu, karung plastik diangkat dari dalam air, kemudian benih padi ditebar di atas bentangan daun pisang (di tempat yang teduh), pada tumpukan bagian atasnya ditutup dengan karung atau dedaunan hijau. Proses pemeraman ini dilakukan selama 2-4 hari yang dikenal sebagai proses perkecambahan benih.

Selanjutnya tahapan persemaian 8-15 hari sebelum tanam sebagai berikut:

a. Pembuatan bedengan dengan ketinggian $10-20 \mathrm{~cm}$ dan lebar $2 \mathrm{~m}$ dengan cara membuat parit/selokan (lebar dan dalam 20cm) setiap lebar 2-3m, sehingga akan terbentuklah bedengan.

b. Sehari sebelum melakukan persemaian, bedengan ditabur pupuk dasar dengan campuran $1 \mathrm{~kg}$ ABG-Bioplus, 10kg bokashi dan 80g ABG-Bio. Persemaian benih dilakukan pada sore hari dengan cara menebar secara merata dan tipis pada lahan bedengan dengan airnya setinggi 
sekitar 0,5-1 cm dari pemukaan bedengan. Selanjutnya pertahankan persemaian dalam kondisi lembab.

Tahap selanjutnya penaburan pupuk dasar dilakukan 1-2hari menjelang pindah tanam (transplanting) yakni pupuk bokashi 4 ton/ha. Supaya pupuk tercampur merata dengan tanah, dilakukan pengadukan bersamaan dengan pencaplakan/penggaritan. Selanjutnya dilakukan pindah tanam bibit padi (semai) pada umur 10-12 hari dengan cara tanam sistem Jajar Legowo dengan 2 anakan per titik tanam. Perawatan padi yang sangat penting adalah penyiangan yang dilakukan pada 10 dan 20 HST (hari sesudah tanam). Penyiangan ketiga sebelum pemberian pupuk susulan pada $35-40 \mathrm{HST}$.

Tahap selanjutnya setelah padi berumur 15 HST diberikan pupuk biostimulan yaitu ABG-Daun 2$3 \mathrm{cc}$ per liter air (sebanyak 2-3 tutup botol ABG per tangki semprot kapasitas 15 liter), disemprotkan pada daun, kemudian dilanjutkan pada 25 dan 35 HST. ABG-D sangat diperlukan untuk merangsang pertumbuhan vegetatif (anakan, akar, daun). Pada umur 45, 55 dan 65 HST dilakukan penyemprotan ABG-Buah secara merata dengan konsentrasi 3-4cc per liter air (3-4 tutup botol per tangki). Pemberian pupuk ABG-B sangat penting untuk vigorsitas, pembungaan, pengisian gabah dan mencegah kerontokan gabah.

Teknologi IPAT-BO dikenal sebagai inovasi teknologi yang hemat air dan sangat cocok diterapkan di lahan kering seperti di NTT. Pengaliran air dilakukan selain untuk memenuhi kebutuhan tanaman, memacu pertumbuhan dan perkembangan perakaran padi, juga untuk meningkatkan populasi dan keaneka-ragaman hayati (kekuatan biologis tanah). Sistem pemberian airnya adalah sebagai berikut :

1. Pada umur 1-8 hari sesudah tanam, pertahankan tanah dalam keadaaan lembab (macak-macak). Keadaan tanah lembab supaya tata udara tanah baik, kemudian menjelang penyiangan pertama digenangi $1-2 \mathrm{~cm}$. Selanjutnya pemberian air jika tanah retak-retak. Setiap penggenangan cukup sekitar 1-2 jam, air dipertahankan agar selalu ada dalam saluran.

2. Pada umur 20 hari sesudah tanam tanaman digenangi air. Hal ini untuk memudahkan penyiangan kedua. Pengaturan pemberian air dilakukan untuk mempertahankan tanah tetap lembab. Untuk merangsang pertumbuhan akar biarkan tanah sampai retak (tapi tanaman tetap segar), jika hujan turun tidak perlu digenangi.

3. Pada awal fase pembungaan hingga padi masak susu (sekitar 25 hari menjelang panen), pertahankan tanah dalam kondisi lembab-macak. Pemberian air dilakukan bila tanah retak-retak sekitar $1 \mathrm{~cm}$. Penggenangan dengan air cukup 1-2 jam.

4. Setelah masak susu, lahan dikeringkan hingga panen

Secara ringkas dapat dilihat pada gambar berikut proses penanaman padi sawah menggunakan teknologi IPAT-BO mulai dari persiapan lahan sampai pada penanaman.

\section{HASIL DAN PEMBAHASAN}

\section{Penerapan IPAT-BO di Desa Bipolo dan Babau di Kabupaten Kupang}

Pengembangan tanaman padi sawah menggunakan sumber air hidup (air dari mata air) dengan menggunakan teknologi IPAT-BO dilaksanakan pada luasan area 4ha pada kelompok tani di desa Bipolo dan Babau, Kabupaten Kupang. Kegiatan pelaksanaan teknologi IPAT-BO tersebut mulai dari pengolahan/persiapan lahan sampai pemupukan dengan biostimulan ABG-D dan ABG-B dilaksanakan sesuai jadwal/kalender IPAT-BO. Pelaksananya adalah anggota kelompok tani dan pendamping tim. Pemupukan pertama dengan pupuk dasar (urea dan TSP) pada umur 10 HST (setelah penyiangan gulma). Pemberian pupuk ABG-D sebanyak 3 kali penyemprotan pada 15, 
25, 35 HST (selang 10 hari). Setelah tanaman mulai berbunga diberikan pupuk ABG-B sebanyak 3 kali semprot selang 10 hari pula (pada 45, 55, 65 HST), selanjutnya menunggu panen. Produksi padi yang dihasilkan di Desa Bipolo dan Babau dapat dilihat pada Tabel 1.
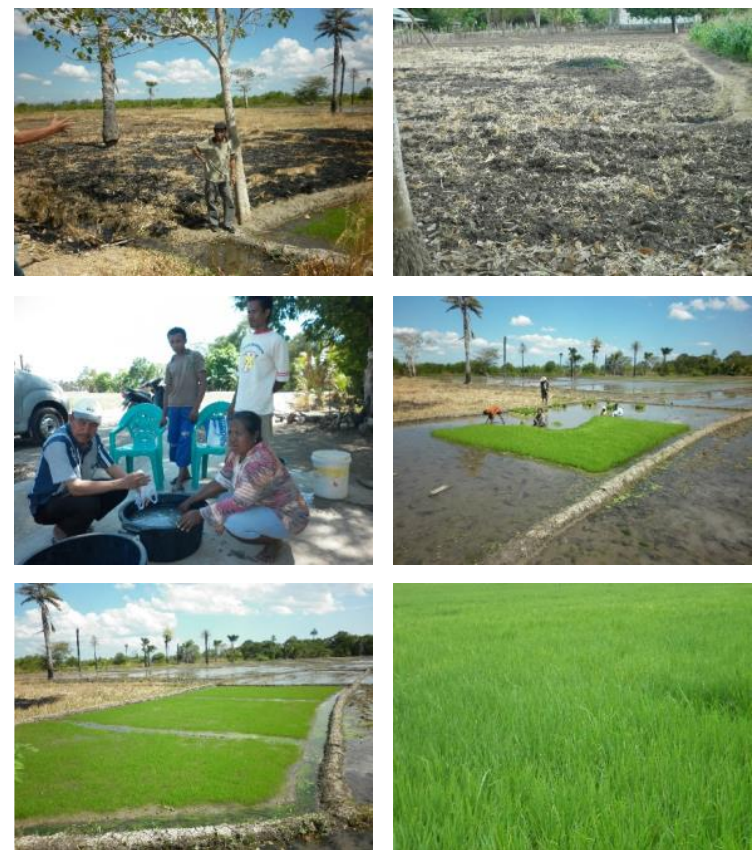

Kegiatan:

1. Olah lahan

2. Pemberian Pupuk Dasar

3. Seleksi Bibit

4. Semai bibit

5. Penanaman

6. Pemberian Urea, TSP, ABG-D, ABG-B

7. Masa bertumbuh

8. Padi mulai berbulir

9. Padi mulai menguning

10. Panen raya
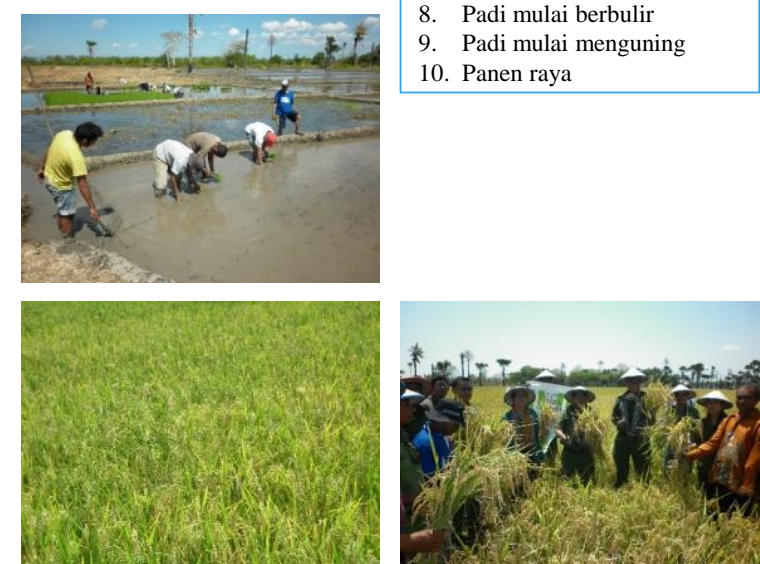

Gambar 1. Proses Penanaman Padi Sawah Menggunakan Teknologi IPAT-BO Mulai dari Persiapan Seleksi Benih, Pemeraman, Persemaian, Tanam Sampai Panen.

Tabel 1 . Produksi padi menggunakan teknologi IPAT-BO di Desa Bipolo dan Babau,

Kabupaten Kupang.

\begin{tabular}{|c|c|c|c|c|}
\hline Desa & Produksi (ton/ha) & $\begin{array}{l}\text { Sebelum dengan } \\
\text { IPAT-BO }\end{array}$ & $\begin{array}{l}\text { Sesudah } \\
\text { IPAT-BO }\end{array}$ & Kenaikan (\%) \\
\hline Bipolo, 2014 & Padi impari-6 & $3-4$ & 6 & 50,7 \\
\hline Bipolo, 2015 & Padi Impari-6 & 4 & 8 & 100 \\
\hline Babau, 2018 & Padi Impari-6 & 4 & 6,8 & 70 \\
\hline
\end{tabular}

Berdasarkan tabel 1 memperlihatkan terjadi peningkatan produksi padi untuk Desa Bipolo sudah mencapai target capaian yaitu terjadi peningkatan sampai 100\%. Sementara di Desa Babau kenaikan produksi baru mencapai $70 \%$. Adanya peningkatan ini terjadi karena kecukupan unsur hara yang tersedia dalam tanah (Simarmata, 2008). Sebagai media tumbuh tanaman, tanah memegang peranan penting dalam mendukung pertumbuhan tanaman. Sifat fisik dan kimia tanah akan menentukan pertumbuhan tanaman, selain penerapan teknik budidaya yang tepat (Goldsworthy \& Fisher, 1996).

Dalam kaitan dengan penerapan teknik budidaya, salah satu yang dapat digunakan adalah melalui pemberian pupuk organik. Keuntungan pemberian pupuk organik adalah dapat memperbaiki sifat fisik tanah (Syarif, 1989). Sifat fisik tanah seperti peningkatan jumlah pori tanah yang memungkinkan tersedianya udara dan air yang cukup bagi pertumbuhan tanaman, memperbaiki strukur tanah yang memberikan pertumbuhan tanaman yang lebih baik (Turmuktini \& Simarmata, 2011).

Peningkatan produksi tanaman padi sangat ditentukan oleh jumlah anakan dalam satu tanaman. Hasil kajian dan demplot di beberapa Provinsi menunjukkan dengan jarak tanam 30x30 $\mathrm{cm}$ (sistem 
caplak) dapat mencapai 60-80 anakan per titik tanam (sistem tanam kembar). Di NTT (Ende, Kupang, Rote Ndao, TTS, TTU, Belu, Sabu Raijua) berkisar 40-60 anakan; sedangkan menggunakan sistem tanam jajar legowo 30-40 anakan. Secara umum diperoleh bahwa jumlah anakan padi dengan menggunakan sistem IPAT-BO berkisar antara 60-80 anakan per tititk tanam. Peningkatan jumlah anakan ini diikuti pula dengan peningkatan jumlah tanaman padi yang menghasilkan malai sehingga total produksi meningkat. Di NTT, hasil demplot kelompok tani di beberapa wilayah dengan pendampingan berkelanjutan dari program IbM, KKN-PPM dan IbW Dikti menunjukkan hasil yang spektakuler dari 6,5 hingga 10,4 ton/ha dibanding secara konvensional yang hanya 3-4 ton/ha (Dami Dato et al., 2009a; 2009b; 2013; Dillak et al., 2012, Ghunu \& Dami Dato, 2007; Maranatha et al., 2007; Tany Temu et al., 2009).

Hasil yang diperoleh dalam kegiatan ini masih lebih rendah dibanding yang dilaporkan Simarmata dan Juwariah (2008) yaitu sebesar 6,8 vs 10-16 ton/ha; Sedangkan dengan menggunakan varietas padi Impari Sidenuk unggulan yang dilakukan di Batu Ampar yang menggunakan teknologi IPATBO menghasilkan produksi sebesar 9-11 ton/ha (Kemenristek Dikti, 2018). Adanya perbedaan ini karena perbedaaan lokasi kegiatan, dimana hasil yang dilaporkan Simarmata dan Juwariah dilakukan di lahan basah, sedangkan hasil yang dilaporkan ini dilakukan di lahan kering. Perbedaan suhu dan lama waktu penyinaran berdampak pada laju fotosintesis tanaman yang menyebabkan terjadi perbedaan hasil fotosintesis antara lahan basah dan lahan kering. Meskipun demikian, penggunaan teknologi IPAT-BO secara umum menyebabkan peningkatan produksi tanaman padi baik lahan basah maupun lahan kering sehingga sangat memungkinkan perbaikan penghasilan petani yang bermuara pada peningkatan taraf hidup petani, disamping ketahanan dan kemandirian pangan.

Respon petani terhadap teknologi IPAT-BO signifikan, terlihat dari keberlanjutan penerapannya setiap musim tanam oleh kelompok tani yang didampingi. Di Desa Bipolo, setelah program IbW berakhir tahun 2015, setiap musim tanam petani menanam padi tetap menggunakan teknologi IPAT-BO karena sudah merasakan peningkatan hasil yang sangat spektakuler (6-8 ton/ha dari konvensional 3-4ton/ha, ada kenaikan hasil panen 100\%), di daerah lainnya kenaikan bahkan mencapai 116-246\%. Difusi atau desiminasi inovasi ini terus berlanjut dan pada tahun 2018 diterapkan di Desa Babau.

Adanya perbedaan produksi tanaman padi program IPAT-BO pada masing-masing lokasi seperti yang dipaparkan diatas menunjukkan bahwa setiap wilayah memiliki karakter cuaca yang berbeda. Disamping itu, sifat dan jenis tanah juga turut menentukan produktivitas tanaman yang diusahakan. Cara penanaman akan menentukan jumlah anakan, dan jumlah anakan akan menentukan besarnya produksi gabah yang dihasilkan (Sutrisna dan Surdianto., 2017).

Dikaitkan dengan era revolusi industri 4.0 saat ini, salah satu aspek dalam revolusi 4,0 adalah adanya peningkatan pengetahuan dan keterampilan masyarakat petani. Peningkatan pengetahuan dan keterampilan masyarakat, berdampak pada adanya perubahan adopsi teknologi. Melalui adopsi teknologi oleh masyarakat, maka peluang peningkatan ketahanan pangan pada sektor pertanian sangat mungkin untuk dicapai melalui penggunaan dan/atau penerapan teknologi IPATBO ini pada lahan sawah baik pada musim hujan maupun pada musim kemarau dengan kondisi air terbatas. Pemasaran produk pertanian dalam bentuk beras siap edar dapat dilakukan secara online sehingga lebih efisien dalam penggunaan waktu dan tenaga. 


\section{Penggunaan Limbah tanaman padi hasil program IPAT-BO}

Upaya peningkatan produksi utama tanaman pertanian melalui penggunaan paket teknologi, pasti diikuti dengan peningkatan produksi limbah yang dihasilkan. Hal ini merupakan dampak langsung dari penerapan teknologi. Limbah yang dihasilkan dari produksi padi IPAT-BO merupakan salah satu produk yang bermutu bagi peningkatan usaha ternak ruminansia. Melalui sentuhan teknologi pengolahan, limbah tanaman padi dapat digunakan sebagai sumberdaya pakan yang potensial. Teknologi amoniasi merupakan salah satu teknologi dalam mendayagunakan limbah tanaman padi sebagai sumber pakan. Dalam kaitannya dengan pengolahan melalui teknologi amoniasi, akan memberikana manfaat yang tinggi terutama peningkatan kandungan protein kasar jerami padi. Dalam proses amoniasi, $\mathrm{N}$ akan berpenetrasi kedalam sel jaringan jerami sehingga sekaligus meningkatkan kandungan nitrogen jerami padi. Peningkatan $\mathrm{N}$ dalam jerami padi akan meningkatkan kandungan protein kasar sehingga dapat memenuhi kebutuhan protein bagi ternak ruminansia.

Pembuatan amoniasi dilakukan dengan metode Trisnadewi (2011) dalam Kleden dan Nenobais (2018) adalah sebagai berikut: Siapkan jerami padi sejumlah $100 \mathrm{~kg}$, urea sebanyak $4 \mathrm{~kg}$ dilarukan dalam air sebanyak 70 liter (perbandingan air:bahan kering adalah 1:1). Selanjutnya jerami dicacah dengan ukuran 3-5 cm. Potongan jerami padi diletakkan di atas alas terpal/plastik dan diperciki dengan larutan urea hingga semua larutan urea yang disiapkan habis dan tercampur merata dan selanjutnya dimasukkan dalam kantung plastik (silo) dan dipadatkan serta diikat dengan kuat sehingga tidak ada udara yang masuk. Silo ditempatkan di tempat yang teduh dan tidak terkena matahari langsung dan dibiarkan selama 3 minggu. Sesudah itu silo dibuka dan jerami dianginanginkan selam 1-2 jam ditempat terbuka dan selanjutnya jerami diberikan pada ternak. Melalui penerapan teknologi amoniasi, upaya penyediaan pakan selama musim kemarau dapat dipertahankan sehingga kekurangan pakan dapat diatasi.

Selain digunakan sebagai sumber pakan bagi ternak, jerami padi yang dihasilkan juga digunakan sebagai sumber pupuk organik dalam bentuk mulsa. Penggunaan jerami padi sebagai mulsa merupakan sumber mulsa yang baik karena memiliki rasio $\mathrm{C} / \mathrm{N}$ besar yang memungkinkan perlindungan tanah yang lebih baik (Seta., 1987). Jerami padi disebarkan diatas pematang diantara tanaman buah-buahan yang berguna dalam mengurangi laju evaporasi. Dengan berjalannya waktu, jerami pada akan mengalami dekomposisi oleh bakteri dan jasad renik yang ada. Proses dekomposisi bahan organik dari jerami padi akan diikuti dengan perbaikan struktur tanah sehingga memungkinkan jumlah pori tanah bertambah baik sebagai ruang yang berisi air maupun udara. Peningkatan kekasaran permukaan akan berdampak pada penurunan energi potensi hujan dan sekaligus penurunan aliran permukaan, disamping sebagai upaya peningkatan agregasi dan porositas tanah, peningkatan kandungan bahan organik serta memelihara temperatur dan kelembaban tanah.

Jerami padi sebagai limbah tanaman padi juga dapat digunakan sebagai bahan dalam pembuatan bokasi. Bokasi jerami padi seperti halnya bokasi jenis lainnya, dengan bantuan bakteri EM4 dalam pembutannya. Jumlah bokasi yang ada akan digunakan sebagai sumber pupuk organik dalam peningkatan produksi padi sistem IPAT-BO periode berikutnya. Dari semua uraian yang sudah digambarkan diatas menyangkut penggunaan limbah jermai padi, menunjukkan bahwa sistem zero waste dalam budidaya tanaman padi merupakan salah satu strategi dalam menjaga keseimbangan lingkungan yaitu mengambil hasil dan mengembalikan hara serta menjamin keberlanjutan usaha. Semua proses yang ada melibatkan masyarakat sebagai mitra pengguna sehingga sangat memungkinkan keberlanjutan program dapat terwujud. 


\section{KESIMPULAN DAN SARAN}

Pengembangan IPAT-BO di Desa Bipolo, Kabupaten Kupang dalam satu tahun sudah dilakukan 2 kali/tahun, pada sawah tadah hujan dengan air dari mata air, hasil panen tahun 2015 sudah mencapai target dengan produksi 8 ton/ha atau mengalami kenaikan $100 \%$.

Pengembangan IPAT-BO di Desa Babau, Kabupaten Kupang baru mulai tanam November 2018 menggunakan air dari sumur bor, hasil panen 6,8 ton/ha atau mengalami kenaikan $70 \%$ yang menunjukkan sangat memungkinkan terjadinya ketahanan dan kemandirian pangan.

Disarankan untuk kelompok tani di Desa Bipolo untuk terus melanjutkan budidaya padi menggunakan teknologi IPAT-BO dengan tahap-tahap pelaksanaan yang menghasilkan gabah sesuai target capaian. Sementara untuk Desa Babau agar meningkatkan produksi padi dengan mengikuti tahap-tahapan pelaksanaan secara benar untuk mencapai produksi sesuai target.

\section{UCAPAN TERIMA KASIH}

Ucapan terima kasih disampaikan kepada DPRM Dikti Jakarta dan PEMDA Kabupaten Kupang yang sudah menyiapkan dana untuk pelaksanaan kegiatan IbW dan saat ini PKW. Disamping itu ucapan terima kasih juga disampaikan kepada Rektor, Ketua LPPM dan Dekan Fapet Undana, Direktur dan Kapus P2M Politani Negeri Kupang, dan kelompok tani di Desa Bipolo dan Babau, yang telah berpatisipasi aktif terlaksananya program IbW ataupun PKW ini.

\section{REFERENSI}

Dami Dato, T. O., M. A. Hilakore, \& M. Raga Lay. (2009a). Pengembangan Potensi Desa Berbasis Pertanian Lahan Kering Menuju Desa Kedaulatan Pangan di Desa Jiwuwu, Kecamatan Sabu Tengah, Kabupaten Sabu Raijua. Laporan KKN-PPM Dikti. LPM Undana, Kupang.

Dami Dato, T. O., S. Ghunu, \& M. A. Hilakore. $\left(2009^{\text {b) }}\right.$. Integrasi Padi-Ternak Melalui Transfer Teknologi IPAT-BO dan Pengolahan Pakan Berbasis Kearifan Lokal dan Ramah Lingkungan Untuk Menunjang Ketahanan Pangan dan Pakan Pada Kondisi Paceklik di Kabupaten Kupang. Laporan IbM, Dikti. LPM Undana, Kupang.

Dami Dato, T. O., M. Raga Lay., \& Prasetyo, D. (2013). IbW Kecamatan Sabu Tengah Kabupaten Sabu Raijua. Laporan IbW Dikti. PM Undana, Kupang.

Dillak, S. T. Y., A. Aoetpah, \& T. O. Dami Dato. (2012). IbW Kecamatan Oenino Kabupaten Timor Tengah Selatan. Laporan Akhir IbW Dikti. LPM Undana, Kupang.

Ghunu, S., \&T. O. Dami Dato. (2007). Pemantapan Program Sibermas untuk Penanganan Rawan Pangan Melalui Sistem Teknologi Intensifikasi Padi Aerob Terkendali Berbasis Organik (IPAT-BO) di Kecamatan Kupang Tengah, Kabupaten Kupang. Laporan Akhir IbW, Dikti. Politeknik Pertanian, Kupang.

Goldsworthy, P.R., \& Fisher, N.N. (1996). Fisiologi tanaman budidaya tropic. Gajah Mada University Press, Yogyakarta.

Hartati, A., Paga, A \& Saleh, A., (2014). IbW di Desa Bipolo dan Oeteta Kecamatan Sulamu Kabupaten Kupang. Laporan Akhir IbW Fakultas Peternakan Universitas Nusa Cendana Kupang

Hartati, A., Paga, A \& Saleh ,A., (2015). IbW di Desa Bipolo dan Oeteta Kecamatan Sulamu Kabupaten Kupang. Laporan Akhir IbW Fakultas Peternakan Universitas Nusa Cendana Kupang

Hingdri, T. T., Yuwariah, Y., Nurmala, T, \& Simarmata.,T (2013). Teknik Pengaturan Air Pada Intensifikasi Padi Aerob Terkendali Berbasis Organik (IPAT-BO) Untuk Meningkatkan 
Populasi Rhizobacteria, Efisiensi Penggunaan Air, Perakaran Tanaman, dan Hasil Tanaman Padi. Agrovigor Vol. 6 (1) 23-29.

Katipana, N., \& Hartati,E. (2012). Budidaya sapi bali di daerah tropis semi kering. Buku Teks. IPB Press.

Kemenristek Dikti. (2018). Tingkatkan Kemampuan Petani dengan Teknologi IPAT-BO. https://www.viva.co.id/

Kleden, M.M \& Nenobais, M.(2018). Upaya pendayagunaan limbah pertanian sebagai pakan unggulan musim kamarau di lahan kering. Jurnal Pemberdayaan Masyarakat ,3(1):213-221

Maranatha, G., M. Raga Lay, \& Y. H. Dimu Heo. (2007). Pemberdayaan Ekonomi Masyarakat yang Berbasis Pada Pertanian Lahan Kering dan Basah di Kecamatan Rote Tengah dan Pantai Baru, Kabupaten Rote Ndao. Laporan Akhir IbW Tahun III, Dikti. LPM Undana, Kupang.

Ningsih, E. M. N. (2014). Macam Teknik Budidaya Terhadap Pertumbuhan dan Hasil Tanaman Padi (Oryza sativa L.). J. Agroland 21(2) 62-68,

Ningsih, E.M. N., \& Suharjanto, T. (2012). Sistem Intensifikasi Padi Aerob Terkendali Berbasis Organik di Kelurahan Tungul Wulung, Kota Malang. AGRIKA, Vol 6(1)13-21.

Simarmata, T. (2008). Teknologi intensifikasi padi aerob terkendali berbasis organik untuk melipatgandakan produksi padi dan mempercepat pencapaian kedaulatan pangan di indonesia. Pidato. Pengukuhan Jabatan Guru Besar. Universitas Padjajaran, Bandung

Simarmata, T., \& Yuwariah, Y. (2008). Teknologi Intensifikasi Padi Aerob Terkendali Berbasis Organik (IPAT-BO) untuk Melipatgandakan Produksi Padi dan Mempercepat Kemandirian dan Ketahanan Pangan. Prosiding. Seminar Apresiasi Hasil Penelitian Padi Menunjang P2BN. Balai Besar Penelitian Tanaman Padi Badan Penelitian dan Pengembangan Pertanian.

Seta, A.K., (1987). Konservasi tanah dan air. Kalam Mulia Jakarta.

Sutrisna N \& Surdianto Y., (2017). Kajian Sistem Intesifikasi Padi Aerob Terkendali Berbasis Bahan Organik (IPAT-BO) untuk Meningkatkan Produktivitas Padi pada Lahan Sawah Tadah Hujan. Prosiding. Seminar Nasional Spesifik Lokasi untuk Ketahanan Pangan pada Era Masyarakat Ekonomi Asean. 81-92.

Syarif, S. (1989). Kesuburan dan pemupukan tanah pertanian. Pustaka Buana, Bandung

Tany Temu, S., N. Gandut, \& T. O. Dami Dato. (2009). Pemberdayaan Potensi Masyarakat Untuk Mendukung Pengembangan Pertumbuhan Ekonomi Petani yang Ramah Lingkungan di Kecamatan Ndona, Kabupaten Ende, Propinsi NTT. Laporan Akhir Tahun III IbW, Dikti. LPM Undana, Kupang.

Turmuktini, T., Simarmata,T., Hersanti, B. N., \& Yuwariah, Y. (2011). Pengujian Inokulan Konsorsium Dekomposer Beragen Hayati dalam Laju Dekomposisi Jerami Selama Masa Inkubasi yang Dilakukan di Rumah Kaca. Jurnal Agribisnis dan Pengembangan Wilayah, 2 (2). 73-83. 